\title{
Events in the Spbere of the Study of Hungarian Legal and Constitutional History in 2017
}

Keywords: scholarly events, Hungary, legal and constitutional history, academic degrees, conferences.

Slowa kluczowe: wydarzenia naukowe, Węgry, historia państwa i prawa, stopnie naukowe, konferencje.

2017 was an eventful year for the study of Hungarian Legal History. I wish herein to present the most important events and works of the legal historians. I concentrated on the scholars and departments of Hungarian and European Legal History only, and left the scholars and departments of Roman Law out of consideration. This study focuses on PhD students' doctoral works and on competition among students. This report also reviews scholarly works in legal history published in Hungary, as well as important legal history conferences in Hungary.

\section{Academic degrees}

1) Dénes Legeza, the professional advisor of the Hungarian Intellectual Property Office, held his public defence of his LL.D. thesis in the University of Szeged. The title of his dissertation was „Egyszer mindenkorra és örökáron”. A szerzői jog és forgalomképessége Magyarországon a reformkortól 1952-ig ['Once and for All'. Copyright and its Transferability in Hungary from the Reform Era to 1952]. ${ }^{1}$ Legeza was a PhD Student of the Department of Hungarian Legal History in the University of Szeged, and his supervisors are Prof. Mária Homoki-Nagy, and Assoc. Prof. Norbert Varga. His reviewers were Assoc. Profs. Csabáné Herger and Gábor Faludi, who recommended the LL.D. thesis for public defense.

1 The thesis was subsequently published: D. Legeza, A kiadói szerzödés története. A reformkortól 1952-ig (The History of Publishing Contract. From the Reform Era to 1952), Szeged 2018. 
2) Talabos Dávidné Lukács Nikolett, a LL.D. student of the Department of History of Law at the University of Debrecen, made her public defence of her LL.D. thesis. The title of her dissertation was "A clausula rebus sic stantibus továbbélése, különös tekintettel a magyar jogfejlődésre" ("The Principle of clausula rebus sic stantibus with Special Regard to Hungarian Legal Development"). Her supervisor was Prof. Béla Szabó, head of the Chair of the History of Law at the University of Debrecen. Her reviewers were Assoc. Prof. Csabáné Herger, and Senior Lecturer Kinga Bódiné Beliznai, who both recommended the conferring of the academic title on her LL.D. thesis.

3) Anna Éva Tamási, an assistant lecturer at the Department of European Legal History at the University of Szeged, was awarded the LL.D. degree as well. Her research topic was Hungarian family law in the $19^{\text {th }}$ century. The title of her thesis was "A veszprémi és a székesfehérvári szentszékek törvénykezési gyakorlata házassági perekben 1850-1920" ("Judicial Practice of the Ecclesiastical Courts of Veszprém and Székesfehérvár in Matrimonial Cases 1850-1920”). Her reviewers were Assoc. Profs. Csabáné Herger and Levente Völgyesi.

\section{National Scientific Students' Associations Conference 2017}

In 2017, the University of Miskolc organized the 33 $3^{\text {rd }}$ National Scientific Students' Associations Conference within the scope of law and political science. This is a scientific competition for the students of the Hungarian faculties of law. The jury is composed of professors of legal history. Papers on legal history were divided into three categories this year: Hungarian Legal and Political History I.; Hungarian Legal and Political History II.; and Universal Legal and Political History.

Péter Sereg (University of Miskolc) won first prize in the category of Hungarian Legal and Political History I. He wrote his competition essay about the Hungarian Royal Curia in the period of the Dual Monarchy (1867-1918). His supervisor was Assoc. Prof. Ibolya Katalin Koncz. In this category, the jury awarded Péter Sándor Sziládi (Eötvös Lóránd University in Budapest) with second prize, Margit Chiara Báró-Farkas, Csaba László Báró-Farkas (co-authors, University of Szeged) and Kristóf Szivós (University of Szeged) with special prizes. ${ }^{2}$

The panel judged Bence Krusóczki's (University of Szeged) competition essay as being the best in the second category of Hungarian Legal and Political History. He analysed the unfair competition in the judicial practice in the first half of the $20^{\text {th }}$ century. ${ }^{3}$

${ }^{2}$ The competition essays of the students of University of Szeged was published: Cs.L. Báró-Farkas, M.C. Báró-Farkas, A cigányságot érintő jogi szabályozás a 20. század második felében (Legislation on Gypsy Population in the Second Half of the $20^{\text {th }}$ Century), "Acta Universitatis Szegediensis. Forum. Publicationes Discipulorum Iurisprudentiae” 2018, vol. 1, no. 1, p. 37-63; K. Szivós, A köszénbányászati jog adományozásának egyes kérdései (Questions on the Donation of the Right of Coal Mining), "Acta Universitatis Szegediensis. Forum. Publicationes Discipulorum Iurisprudentiae” 2018, vol. 1, no. 1, p. 627-658.

${ }^{3}$ B. Krusóczki, A tisztességtelen verseny a Szegedi Királyi Ittélötábla joggyakorlatában (The Practical Implementation of the Unfair Competition in the Royal Courts of Appeal in Szeged), "Acta Universitatis Szegediensis. Forum. Publicationes Discipulorum Iurisprudentiae” 2018, vol. 1, no. 1, p. 245-269. 
His supervisors were Prof. Mária Homoki-Nagy and Assoc. Prof. Norbert Varga. Enikő Szépvölgyi (Széchenyi István University in Győr) finished second, and Máté Suhajda (University of Pécs) came in third. The competition essay of György Attila Németh was also recognized with a special prize of Ministry of Justice ${ }^{4}$.

First place in the Universal Legal and Political History category went to Kamilla Galicz (University of Pécs), who also won a special prize of HVG ORAC Publishing House. The topic of her dissertation was Pietro Verri, who was an Italian polyhistor of the Enlightenment, who played a significant role in the creation of Beccaria's famous work, "On Crimes and Punishments". Her supervisor was Assoc. Prof. Csabáné Herger. Fanny Rose Vincze and Patrícia Dominika Niklai also received awards in this category.

\section{Scholarly research}

In 2017, a general work about Hungarian Legal and Constitutional History was published in German. ${ }^{5}$ This work was the product of a cooperative effort among Hungarian legal historians with the support of the National University of Public Service. The chief editor was Gábor Máthé, who strengthened harmony among the authors during the work. Individual chapters were written by researchers recognized for their expertise in the given subject.

The specific topics of research were determined by the focus of the jurisdictional organization. There were numerous scholarly works and conferences which dealt with this subject in 2017 just as they had in 2016. These works of research in judicial history were supported by the National Office for the Judiciary.

Three particular works dealt with the history of local courts. Assoc. Prof. Tamás Antal (LL.D., Dr. Habil) of the Department of European Legal History at the University of Szeged, wrote a monograph about the Royal Appeal Court in Szeged during the interwar period. ${ }^{6}$ This is the third part of the series titled "Chapters from the Royal Appeals Court in Szeged", in which the author analysed the important cases from the practice of the Court on the basis of archive material. Another academic work was completed in the Department of Hungarian Legal History in Szeged, which treated with the private law practice of the Szeged Court of Justice. ${ }^{7}$ This work is the third part of the "History of the Szeged Court of Justice" series. The authors presented the most important legal institutions of Hungarian private law by means of the judgements of the Court between 1890 and 1945.

\footnotetext{
${ }^{4}$ Gy.A. Németh, A vegyes házasságok jogtörténete 1832 és 1844 között, különös tekintettel Csanád vármegyére (The History of Mixed Marriage between 1832 and 1844, with Special Regard to Csanád County), "Acta Universitatis Szegediensis. Forum. Publicationes Discipulorum Iurisprudentiae" 2018, vol. 1, no. 1, p. 447-477.

${ }^{5}$ Die Entwicklung der Verfassung und des Rechts in Ungarn, ed. G. Máthé, Budapest 2017.

${ }^{6}$ T. Antal, A Szegedi Királyi Ítélótábla története 1921 és 1938 között (A History of the Royal Appeal Court in Szeged between 1921 and 1938), Budapest-Szeged 2017.

${ }^{7}$ M. Homoki-Nagy, M. Pétervári, B. Krusóczki, A Szegedi Törvényszék története (The History of Szeged Court of Justice), vol. 3, Szeged 2017.
} 
The history of one small town's jurisdiction was published through cooperation within the Department of Legal History in Debrecen. The authors examined the judicial organs of Berettyóújfalu from the $17^{\text {th }}$ century to 1949 . Three legal historians participated in the work: Judit Balogh, ${ }^{8}$ László Papp, ${ }^{9}$ and Zoltán Megyeri-Pálffi. ${ }^{10}$

The National Office for the Judiciary organized a conference about the history of courts in the former building of the Hungarian Royal Curia in 2017. These lectures were published in a special issue of the Hungarian journal of legal history, the Jogtörténeti Szemle (Review of Legal History), which contains 17 essays by researchers from all Hungarian universities. The introduction to this issue was written by the president of the National Office for the Judiciary, Tünde Handó. Péter Nagy (Károli Gáspár University) and István Stipta (Károli Gáspár University, University of Szeged) presented legal historical works about the history of the judiciary in their papers. ${ }^{11}$ Barna Mezey (Eötvös Lóránd University), Gábor Béli (University of Pécs), Béla Szabó (University of Debrecen), Elemér Balogh (University of Szeged), and Attila Barna (Széchenyi István University in Györ) dealt with issues of jurisdiction during the feudal era in their studies. ${ }^{12}$ Judit Balogh (University of Debrecen) wrote about the Royal Courts of Appeal in Debrecen, ${ }^{13}$ and Tamás Antal (University of Szeged) examined the establishment of the common jury in Hungary. ${ }^{14}$ Kinga Bódiné Beliznai and Zoltán Megyeri-Pálffi dealt with

8 J. Balogh, Mozaikok a Berettyóújfalui Királyi Járásbíróság történetéböl (1872-1949) (Mosaics from the history of Berettyóújfalu Royal District Court (1872-1949) [w:] Ajogszolgáltatás története Berettyóújfaluban (History of Justice in Berettyóújfalu), ed. Z. Megyeri-Pálffi, Debrecen 2017, p. 44-55.

${ }^{9}$ L. Papp, Bihar vármegyei törvényszékek a 17. századtól 1871-ig (County Courts of Bihar County as from the 1 $7^{\text {th }}$ Century until 1871) [w:] A jogszolgáltatás története Berettyóújfaluban (History of Justice in Berettyóújfalu), ed. Z. Megyeri-Pálffi, Debrecen 2017, p. 15-21.

${ }_{10}$ Z. Megyeri-Pálffi, A Berettyóújfalui Járásbíróság épületének története (History of the buliding of Berettyóújfalu District Court) [w:] A jogszolgáltatás története Berettyóújfaluban (History of Justice in Berettyóújfalu), ed. Z. Megyeri-Pálffi, Debrecen 2017, p. 57-67.

${ }_{11}$ P. Nagy, A hazai bíróság-történet szakirodalma (The Literature of the National History of the Judiciary), „Jogtörténeti Szemle” 2017, vol. 19, no. 1-2, p. 141-148; I. Stipta, Bírósági szervezettörténet a hazai jogtörténet-tudomány tükrében (The History of Judicial Establishment in Light of National Legal History Science), „Jogtörténeti Szemle” 2017, vol. 19, no. 1-2, p. 2-10.

12 B. Mezey, Törvények s törvényszékek javitásának gondja (A felsőbíráskodás szervezetének átalakitása a 18. században) (The Troubles of the Acts and Courts'Bettering (The Rebuliding of the Higher Court in the $18^{\text {th }}$ Century)), ,Jogtörténeti Szemle” 2017, vol. 19, no. 1-2, p. 10-20; G. Béli, A vármegyei nemesi bíráskodás szervezete 1723-ig (The Organization of the Nobles'Judging in the Counties until 1723), „Jogtörténeti Szemle" 2017, vol. 19, no. 1-2, p. 21-31; B. Szabó, Az erdélyi szászok bíráskodási szervezete a korai újkorig (The Organization of the Transylvanian Saxons' Judging Until the Early Modern Period), „Jogtörténeti Szemle" 2017, vol. 19, no. 1-2, p. 31-40; E. Balogh, Az egyházi bíráskodás európai modelljei a középkorban. Összehasonlitó elemzés a középkori német és magyar intézményi struktúráról (European Modells of the Ecclesiastical Jurisdiction in the Middle Ages. Comparative Analysis about the Medieval German and Hungarian Institutional Structure), ,Jogtörténeti Szemle” 2017, vol. 19, no. 1-2, p. 41-51; A. Barna, Rendes és rendkivüli bíróságok a hütlenségi perek perjogi szabályozásában és itélkezésében a középkori Magyar Királyság felosztásáig (Regular and Irregular Courts in the Procedural Regulation and Litigation of the Infidelity Cases), „Jogtörténeti Szemle” 2017, vol. 19, no. 1-2, p. 51-57.

13 J. Balogh, A felsöbíráskodás megszervezése Debrecenben (The Organization of the Higher Court in Debrecen), ,Jogtörténeti Szemle” 2017, vol. 19, no. 1-2, p. 57-63.

${ }^{14}$ T. Antal, Az esküdtszék fogadtatása az 1896. évi bünvádi perrendtartás országgyülési vitájában (The Reception of the Jury in the National Assembly's Debate of the Criminal Code 1896), „Jogtörténeti Szemle” 2017, vol. 19, no. 1-2, p. 64-71. 
the issue of the building which housed the Royal Curia, ${ }^{15}$ since the Hungarian government intends to require the Curia to return to those headquarters. Three authors analysed a particular irregular courts: Ibolya Katalin Koncz (University of Miskolc) examined the Competence Court, László Papp (University of Debrecen) studied patent jurisdiction, and István Szabó (Pázmány Péter Catholic University) dealt with the Cartel Court. ${ }^{16}$ Béla Révész (University of Szeged) and Attila Horváth (Eötvös Lóránd University, National University of Public Service) wrote about the judicial system during the communist era. ${ }^{17}$ Miklós Kengyel (Károli Gáspár University) presented the historical values of the Hungarian judiciary. ${ }^{18}$

Roland Kelemen published three books during the course of the examined years. He also authored a monograph about jurisdictional issues with the support of the Ministry of Justice. In his work he examined military jurisdiction after the Austro-Hungarian Compromise until the communist era. ${ }^{19}$ A shortened version of this book was also released in English. ${ }^{20}$ Besides this, the assistant lecturer of Széchenyi István University in Győr researched Act 63 of 1912 about the extraordinary situation (kivételes hatalom) with many original sources. ${ }^{21}$

In 2017, new papers were published as part of the "Rechtsgeschichtliche Vorträge/ Lectures on Legal History" series, which is issued by the Department of Legal and Constitutional History in Eötvös Lóránd University. The work by Kinga Bódine Beliznai dealt with judicial independence in Hungary during the Dualist Period. ${ }^{22}$ Moreover, a classic monograph was also published in the same year. Herger Csabáné (University of Pécs) is a researcher of the history of family law. She had previously examined Hungarian marriage law. In the examined year, she published a new book about marital property systems, ${ }^{23}$ in which she compared the Hungarian and the German system from the

15 K. Bódiné Beliznai, 120 éves az Igazságügyi Palota (Palace of Justice is 120 Years Old), „Jogtörténeti Szemle” 2017, vol. 19, no. 1-2, p. 71-87; Z. Megyeri-Pálffi, Az igazságügyi szervezet a fizikai valóságban: a Kúria épülete (The Judicial Organization in the Physical Reality: The Buliding of the Curia), „Jogtörténeti Szemle" 2017, vol. 19, no. 1-2, p. 87-96.

${ }^{16}$ I.K. Koncz, A Hatásköri Bíróság Magyarországon (The Competence Court in Hungary), ,Jogtörténeti Szemle" 2017, vol. 19, no. 1-2, p. 96-103; L. Papp, A szabadalmi bíráskodás szervezeti kérdései (The Organizational Questions of the Patent Jurisdiction), „Jogtörténeti Szemle” 2017, vol. 19, no. 1-2, p. 104-110; I. Szabó, A Kartellbíróság (1931) (The Cartel Court (1931)), „Jogtörténeti Szemle” 2017, vol. 19, no. 1-2, p. 111-118.

17 B. Révész, Változások a bírósági rendszerben 1945 és 1989 között (Changes in the Judicial System between 1945 and 1989), „Jogtörténeti Szemle” 2017, vol. 19, no. 1-2, p. 118-127; A. Horváth, A magyar bírósági szervezet története a szovjet típusú diktatúra idején (1945-1990) (The History of the Hungarian Judicial Organization in the Time of the Soviet Type Dictatorship), „Jogtörténeti Szemle” 2017, vol. 19, no. 1-2, p. $128-132$.

${ }_{18}$ M. Kengyel, A jelenkori birósági rendszer történeti értékei (The Historical Values of the Contemporary Judicial System), „Jogtörténeti Szemle” 2017, vol. 19, no. 1-2, p. 133-140.

19 R. Kelemen, A katonai igazságszolgáltatás Magyarországon (1867-1949) (Military Jurisdiction in Hungary (1867-1949)), Budapest 2017.

${ }^{20}$ Idem, Military Jurisdiction in Hungary at the Time of the Dualism (1867-1918), Budapest 2017.

${ }^{21}$ Idem, Források a kivételes hatalom szabályozásának magyarországi geneziséröl (Sources about the Hungarian Genesis of the Extraordinary Power's Regulation), Budapest 2017.

${ }^{22}$ K. Bódiné Beliznai, Sind Richter bestechlich? Materielle Unabhängigkeit der Richter in Ungarn (1870-1920), Budapest 2017.

${ }^{23}$ Cs. Herger, A modern magyar házassági vagyonjog kialakulása és rendszere a német jogfejlödés tükrében (The Formation and System of the Marital Property System in Light of German Legal Development), Passau 2017. 
$19^{\text {th }}$ century to the present. The author analysed the influence of the German law on the Hungarian regulations.

The Kartel-jogtörténeti Kutatócsoport (Research Group of Cartel History) was formed in 2015 with the cooperation of the Department of the History of Law in Pázmány Péter Catholic University and the Department of Hungarian Legal History of the University of Szeged. This project continued with support from the Hungarian Competition Authority in 2017, too. In 2016, the Research Group examined the birth and implementation of Act 20 of 1931 which was the first Hungarian Cartel Act, as well as the new organs of this Act, the Cartel Court and the Cartel Committee. The researchers explored the legal practice of Cartel Law between 1931 and 1945 in the second phase. The participants made their academic accomplishments known at the conference entitled "Kartelljog múltja (The History of Cartel Law)" in Szeged on 22 September 2017. The results of the research were published in a special issue of Versenytükör, the journal of the Hungarian Competition Authority. ${ }^{24}$ Research related to the cartel law has become more active due to an initiative of the Hungarian Competition Authority in the last few years. ${ }^{25}$

In 2017, a new ten-member research group was founded with the support of National University of Public Service in the Department of Hungarian Legal History at the University of Szeged, which examined the history of professions in public administration and jurisdiction. The researchers made their first achievments known at the headquarters of the Academic Commission of Szeged on 6 October 2017. A portion of their research was published in the journal of the Faculty of Law of the University of Szeged. ${ }^{26}$

${ }^{24}$ M. Homoki-Nagy, Kartellszerzödések a gyakorlatban (Cartel Contracts in the Practice), „Versenytükör” 2017, vol. 13, Különszám (special issue), p. 4-13; Gy. Kovács, A kartellkérdés gazdaságelméleti és gazdaságpolitikai háttere II. (The Economic Theoretical and Political Background of the Cartel II.), „Versenytükör" 2017, vol. 13, Különszám (special issue), p. 14-34; I. Szabó, Az 1931. évi XX. törvénycikk rendes biróságok elötti gyakorlata (The Practice of the Regular Courts in the Cartel Questions), „Versenytükör” 2017, vol. 13, Különszám (special issue), p. 35-45; N. Varga, Birrságolási eljárási szabályok kartellügyekben az 1931. évi XX. tc. hatálybalépését követöen (The Regulation of the Fining Procedures in the Cartel Cases Following the Comming Into Force of the Act 20 of 1931), „Versenytükör” 2017, vol. 13, Különszám (special issue), p. $46-56$.

${ }^{25}$ I. Szabó, Jogesetek az elsö magyar kartelltörvény gyakorlatából (1931) (Legal Cases From the Practice of the First Hungarian Cartel Act (1931)) [w:] 60. Studia in honorem Péter Miskolczi-Bodnár, eds. Á.O. Homicskó, R. Szuchy, Budapest 2017, p. 489-502; N. Varga, The procedure and operation of the Cartel Court [w:] Lege et fide: ünnepi tanulmányok Szabó Imre 65. születésnapjára, eds. K. Gellén, M. Görög, Szeged 2016, p. 660-669; idem, A kartellszerződések választott bírósági eljárásra vonatkozó rendelkezései a polgári korban (The Provisions of the Cartel Contracts Concerning the Arbitratral Jurisdiction in the Bourgeois Age) [w:] Risus cum lacrimis. Könyv Babják Ildikó emlékére, eds. B. Szabó, E. Újvári, Debrecen 2017, p. 281-293; idem, The Cartel Policy in the Cartel Law Special Attention to the First Cartel Act in Hungary [w:] Honori et virtuti. Ünnepi tanulmányok Bobvos Pál 65. születésnapjára, ed. K. Gellén, Szeged 2017, p. 463-468; idem, Adalékok a Kartelbizottság müködéséhez a 20. században (The Contributions to the Functioning of the Cartel Commission in the $20^{\text {th }}$ Century) [w:] 65. Studia in honorem István Stipta, eds. J. Balogh et al., Budapest 2017, p. 480-489; idem, The Basic Principles of Code of Civil Procedure in Cartel Law in the $20^{\text {th }}$ Century [w:] Lege duce, comite familia. Ünnepi tanulmányok Tóthné Fábián Eszter tiszteletére, jogászi pályafutásának 60. évfordulójára, eds. M. Görög, A. Hegedüs, Szeged 2017, p. 505-511; idem, A kartell-eljárásjogi szabályok bemutatása: Egy konkrét ügy kapcsán (The Presentation of the Cartel Procedural Law, with Reference to a Concrete Case) [w:] Ünnepi kötet Dr. Nagy Ferenc egyetemi tanár 70. születésnapjára, eds. M. Homoki-Nagy et al., Szeged 2018, p. 955-962.

${ }^{26}$ T. Almási, Hermán nembéli Lampert királyi országbiró müködésének okleveles adatai (Certified Data on the Deeds of Lampert From the Kindred Hermán, Royal Judge), „Acta Universitatis Szegediensis. Forum. Acta Juridica et Politica" 2017, vol. 7, no. 1, p. 5-29; T. Antal, A trianoni békeszerzödés hatásai a királyi 


\section{Collection of essays and conferences}

István Stipta, who currently works for Károli Gáspár University, was previously Professor of Legal History at the University of Miskolc. His research topic is the history of Hungarian public administration and jurisdiction. His several studies, which were focused mainly on Hungarian public administration, were published in German in 2005. ${ }^{27}$ In 2017 Stipta's colleagues celebrated the $65^{\text {th }}$ year of his birth by producing a volume of studies. The book contains 35 papers from Stipta's admirers. ${ }^{28}$ A formal celebration was organised by the Károli Gáspár University on 16 March 2017.

Gábor Máthé is a Professor Emeritus of the National University of Public Service, who teaches the history of public administration and legal history. He wrote his candidate's thesis about the formation of the Hungarian jurisdictional organization after the Austro-Hungarian Compromise. He habilitated in 2007, the title of his habilitation's work was Die Problematik der Gewaltentrennung. ${ }^{29}$ He dealt with the history of administrative criminal law in many publications. His colleagues congratulated him on the $50^{\text {th }}$ anniversary of his teaching career by presenting him with a volume of studies on 26 October 2017. This book contains 42 studies, which were edited by Norbert Kis and Zsuzsanna Peres. ${ }^{30}$

In 2017, the conference proceedings volume with the title of "Tripartitum trium professorum" Három szegedi jogtörténész (Three Legal Historians of Szeged) was published. ${ }^{31}$ The conference was held in 2014, and was dedicated to the centenary of the birth of György Bónis, the $90^{\text {th }}$ anniversary of the birth of Ödön Both, and the $50^{\text {th }}$ anniversary of the death of Béla Iványi. They were outstanding teachers of the School of Legal History of Szeged. 2014 was the $500^{\text {th }}$ anniversary of the Tripartitum, the most important Hungarian custumal, which determined Hungarian private law until the $20^{\text {th }}$ century. For this reason, eleven authors dealt with the Tripartitum in their papers. This book contains 26 papers from the field of legal history. 12 of the essays are in German, and five German professors published their works in the volume.

itélötáblákra - különös tekintettel a szegedire (Effects of the Peace Treaty of Trianon on the Operation of the Appeal Courts in Hungary - with Special Regard to Szeged), „Acta Universitatis Szegediensis. Forum. Acta Juridica et Politica" 2017, vol. 7, no. 1, p. 31-44; M. Homoki-Nagy, A bírói felelősség az 1869: IV. tc. alapján (The Judicial Responsibility on the Basis of Act IV of 1869), „Acta Universitatis Szegediensis. Forum. Acta Juridica et Politica" 2017, vol. 7 no. 1, p. 45-68; L. Papp, Különbíróságok szerepe és rendeltetése a modern igazságszolgáltatási rendszerekben (The Role and Function of Special Courts in the Modern Jurisdictional System), „Acta Universitatis Szegediensis. Forum. Acta Juridica et Politica” 2017, vol. 7, no. 1, p. 69-82; G. Rokolya, Leszámolás a polgári közjegyzőkkel (1945-1956) (Retribution Against Civil Law Notaries (1945-1956)), „Acta Universitatis Szegediensis. Forum. Acta Juridica et Politica” 2017, vol. 7, no. 1, p. 83-97.

${ }^{27}$ I. Stipta, Die vertikale Gewaltentrennung (Verfassungs- und rechtsgeschichtliche Studien), Budapest 2005.

2865 Studia in honorem István Stipta, eds. J. Balogh et al., Budapest 2017.

29 G. Máthé, Die Problematik der Gewaltentrennung, Budapest 2004.

30 Ünnepi tanulmányok Máthé Gábor oktatói pályafutásának 50. jubileumára (Festive Studies on the Occasion of 50 th Anniversarsy of Máthé Gábor's Teaching Career), eds. N. Kis, Zs. Peres, Budapest 2017.

31 Tripartitum trium professorum. Három szegedi jogtörténész. Drei Szegediner Rechtshistoriker (Three Legal Historians of Szeged), eds. E. Balogh, M. Homoki-Nagy, Szeged 2017. 
In 2015 Pázmány Péter University organized an international conference concerning state jurisdiction, and subsequently published the edited lectures in 2017. While the volume is published in German, the authors are Hungarian, Austrian, Polish, and Czech researchers. ${ }^{32}$ The legal historians of Eötvös Lóránd University also presented a collection of essays in German about the questions of criminal law history. ${ }^{33}$

Most of the legal historians of Hungary participated in the Legal History Days of Szeged VII, which were organized on 6-8 December 2017. The topic of the conference was the Austro-Hungarian Compromise and Tripartitum. A new feature of this traditional event was the first day, when the Hungarian $\mathrm{PhD}$ Students presented their research works. The occasion was very popular, and $12 \mathrm{PhD}$ students gave lectures.

Beyond the many cheerful events in the society of Hungarian legal historians, there was also a tragic event in 2017. József Ruszoly, Professor Emeritus of the University of Szeged, died on 24 September. He was a recognized authority on voting rights, European legal history, and Hungarian constitutional history of the $19^{\text {th }}$ and $20^{\text {th }}$ century. He worked for the University of Miskolc as well as for the University of Debrecen. He published his most important research works in German. ${ }^{34}$

32 Staatsgerichtsbarkeit in Mitteleuropa, eds. G. Kohl, I. Szabó, Budapest 2017.

${ }_{33}$ Die Auswirkungen politisch-sozialer Umbrüche auf das Strafrecht, ed. B. Mezey, Budapest 2017.

${ }^{34}$ J. Ruszoly, Beiträge zur neueren Verfassungsgeschichte, Budapest 2009. 